\title{
Gesture-based Interaction: Concept Map and Application Scenarios
}

\author{
José A. Gallud \\ LoUISE Group \\ University of Castilla-La Mancha \\ Albacete, Spain \\ jose.gallud@uclm.es \\ Gabriel Sebastián \\ LoUISE Group \\ University of Castilla-La Mancha \\ Albacete, Spain \\ gabriel.sebastian@uclm.es
}

\author{
Pedro G. Villanueva \\ LoUISE Group \\ University of Castilla-La Mancha \\ Albacete, Spain \\ pedro.gonzalez@uclm.es \\ Sylvia Molina \\ Indevol Group \\ University of Castilla-La Mancha \\ Cuenca, Spain \\ sy.molina@uclm.es
}

\author{
Ricardo Tesoriero \\ LoUISE Group \\ University of Castilla-La Mancha \\ Albacete, Spain \\ ricardo.tesoriero@uclm.es
}

\author{
Ana Navarrete \\ Indevol Group \\ University of Castilla-La Mancha \\ Cuenca, Spain \\ ana.navarrete@uclm.es
}

\begin{abstract}
Nowadays the new interaction forms proposed tend not to be limited by graphic interfaces and make human computer interaction . Nowadays, Human-Computer Interaction (HCI) is not limited by Graphical User Interfaces (GUIs). There is a tendency to make it more natural and human. This paper presents a novel interaction approach within the scope of gesture-based interfaces, and some practical consequences of adopting this approach. Thus, we redefine the concept of gesture based on the sum of three interrelated concepts (the Para-language, the Body language and the Sound language). The relationships among these concepts are expressed in a conceptual map through parameterized links. Finally the article shows how the combination of the link parameters yields to the definition of a specific application scenario. The result of the identification of these scenarios opens new horizons towards the identification of new ways of gesture-based interaction.
\end{abstract}

Keywords-Human-computer interaction; gesture-based interfaces; User information access information.

\section{INTRODUCTION}

Interactive systems are undergoing deep changes as consequence of today's technological development. Up to recently, every effort was focused on developing Graphic User Interfaces (GUIs) where the User Centered Design (UCD) criteria was predominant. However, the concept of interface has gone beyond the limits set by GUIs, making its way to the so-called Human User Interfaces (HUIs) [1].

The high complexity of the technologies currently used in the field of Human-Computer Interaction (HCI) may be attributed to the dramatic changes, which have newly defined our relationship with technology. These changes have encouraged us in the search to identify new application scenarios, with user gesture sensitive devices.

This article provides some conceptual tools to understand the high complexity of the interaction in current systems. More specifically, we propose the widening of the gesture concept as the sum of three other concepts (non-verbal communication types): Para-language, Body language and Sound language.

The proposal itself embraces the form to systematize a multiplicity of possible scenarios basing on concept structure -using concept maps- that define the gesture (non-verbal voluntary communication), for subsequent parameterization of these elements (using tables of parameters) in a method of extension of the basic information presented and the user information, contextualized in the said scenarios.

The rest of the paper is structured as follows: Section II presents some related works showing different approaches to interaction in gesture-based applications. Section III describes our study on the concept of gesture-based interaction and its representation in a concept map and in parameter tables. Section IV presents the result of the concept parameter combination included in the concept map. It also shows, using examples, how to identify new scenarios and new interaction forms. Finally, conclusions are presented, also explaining future works being currently undertaking.

\section{RELATED WORK}

Saffer [2] states that a gesture is any physical movement, which a digital system can detect and be replied to, with no assistance from a traditional leading device. A sound, nodding one's head or even winking may be considered gestures. Thus, one of the current problems in contextaware applications is gesture recognition. If we manage to use the user intervention by means of his/her Body and Sound language, we will have the possibility to create new interfaces the user can interact with in a natural and human form with the physical environment; that is, our purpose to make the environment interact (be restructured) depending on the user will be fulfilled. In this sense, we should also mention the works performed by Moggridge [3], Tidwell [4] and Norman [5] [6]. 
The research on creativity and innovation on HCI is also exposed in Shneiderman's works [7] [8] [9]. In the field of tangible interfaces we highlight the work of Ishii [10].

In [11], Sellen et al. write on the end of the stability of interfaces, meaning that computers cannot be defined any more with reference only to a single interface, but rather to different interfaces or even to no interface at all.

Following this approach, which intends to dispense with the user interface, there are some examples of novel interaction that may well illustrate the relevance of the proposal presented in this paper.

In the design and usability Blog MakeMeMinimal, the $3 \mathrm{D}$ graffiti is presented as the innovative usability prototype [12]. 3D graffiti is based on gesture interaction for graffiti creation in 3D whose canvas is Augmented Reality. Another example is the commercial product Panasonic's Interactive TV Wall [13], which uses gesture interaction based on the user movements facing the screen/wall. An interesting example of interaction based on tactile gestures by means of the printing and its duration is the multi-touch screen Crazy Multi-Input Touch Screen [14].

\section{STUdy OF THE CONCEPT OF GESTURE-BASED INTERACTION: A CONCEPT MAP}

Flusser [15] states that "gestures are body movements, which express an intention". In this section, the gesture concept will be extended, describing also our proposal of gesture-based interaction. Non-verbal communication is communication performed using cues and signals with no syntactic structure. There are three different types: Paralanguage, Body language and Sound language. Through the addition of these three new concepts, the concept of gesture can be extended.

- The Para-language refers to the elements, which accompany linguistic emissions and constitute non-verbal clues and signs, which contextualize or suggest different interpretations of the linguistic information. It is characterized by voice intensity or loudness, speed of emission of the statements, pitch (and intonation variants and syllable duration) and finally, crying, laughter, rhythm, fluency, control of respiratory and articulatory organs, etc.

- The Body language is understood as the type of language developed using gestures but with the particular distinctive characteristic of using the body (trunk), the extremities and the head to be developed; on these grounds, there would be different parameterized concepts, which are:

- Orientation based on body pose, that is, at the moment in which body, face and extremities interact in an unidirectional or multi-directional manner.

- The Proximity refers to whether gesture interaction must be performed parameterized in relation to closeness, distance or indetermination.
- The Pose or Form depends on its pose or form, with motion or without it.

- The Speed defines whether interaction is performed rapidly or slowly.

- The Expression is the body pose expression of the user during the intervention; there could be an infinite number of expressions, but we have parameterized them in: Complicity, Honest, Clear, Doubt, Happy, Sickly, Rational, Intimate, Relaxed, Social, Lunatic, Calm.

- The Sound language can be defined as the type of language developed using gestures but with the particular feature of using sounds as well. Its characteristics are: volume, Pitch and Speed. The concepts conforming Sound language are:

- The Emotional element would be the equivalent to the expression in Body language, depending on our sound intervention at the moment. Thus, the interaction may vary depending on the following elements: complicity, honesty, sound cleanness, doubt, joy nuances, sickly nuances, rationality, intimateness, calmness, social, lunatic, relaxed nuances, etc.

- The Context sound is referred as the sound context of the context of our sound interaction: the way it will be, whether just a single sound or along with by more sounds.

- The Internal sound is parameterized in relation to the sound elements, which can be a melody, music, some noise and in general anything that could be a sound and at the same time silence.

- The External sound It is parameterized in the same way as the Internal concept.

To be able to express the widening of the Gesture concept, we have elaborated a concept map. From this map, we have derived a concept tree that defines a descriptive model showing the ramifications and relations among concepts. As consequence, we can observe that there are no concepts, situations, parameters or contexts, defined individually or not related to the rest. The concept map proposed for gestures is shown in Figure 1.

Let us now move down our level of abstraction and pass from a conceptual level to specific cases starting from the combination of the parameters studied at that conceptual level. For that purpose we are going to show the concepts included in the map in three tables, which will help us analyze all possible combinations.

In this paper, we will focus on the parameterization of the concepts that form Body Language and Sound language. Table I shows in detail Body language parameters on innate or natural gestures, which are put before Body language on acquired or learnt gestures; the table includes the concepts - which have been previously explained- constituting Body 


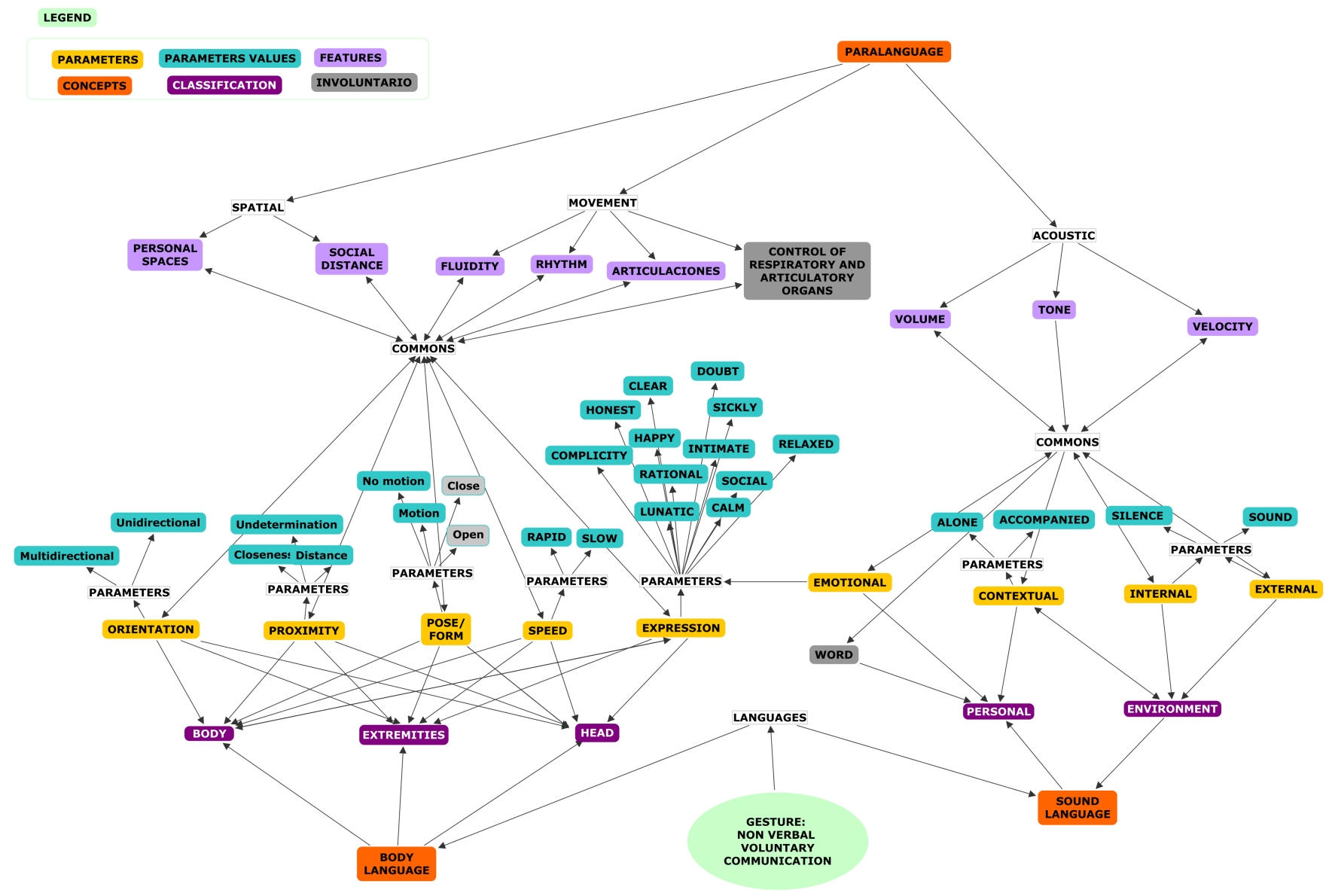

Figure 1. Concept map

language: Orientation, Proximity, Pose/form, Speed and Expression, taking into account the possible values implied by those concepts and the part of the body used in each case.

Table II shows the parameters of Body language concerning acquired or learnt gestures and presents the same structure as Table I previously explained.

Finally, Table III presents the parameters of Sound language concerning natural gestures. This table logically presents a different structure from the previous tables; thus, it can be observed that Sound language is composed of the concepts: Emotional, Context, Internal and External.

\section{IDENTIFICATION OF APPLICATION SCENARIOS}

Let us show now how a huge number of application scenarios can be obtained in a systematic form with gesture interventions using different combinations of the parameters shown in the tables of Body language and Sound language. With this systematic generation of scenarios, we can obtain unusual scenarios, which otherwise would be complicated to imagine. These scenarios, in turn, will allow the identification of existing ways of interaction as well as many new forms.
In order to perform the mentioned combination to expand parameters, we need to create a table containing Body language and Sound language parameters in the columns. By changing one or more parameters in each raw, a specific scenario can be obtained

\section{A. Quantification of map parameters}

Before performing the mentioned combination expansion we need to state clearly and quantify the possible values for each parameter.

In this subsection the possible values of the parameters of the tables of Body language and Sound language separately. We will need to establish whether the parameters of each category are mutually exclusive and the range or set of values that can be used.

The parameters from the original tables to be combined are described in Figure IV.

As shown in Table IV, the concept of Body language is composed of seven parameters: orientation, proximity, pose or form, speed, expression, gesture type and place. Let us now examine the possible values for each parameter listed: 
Table I

BODY LANGUAGE OF NATURAL GESTURES

\begin{tabular}{|c|c|c|c|c|}
\hline \multicolumn{5}{|c|}{ Gesture. Non-verbal communication } \\
\hline \multicolumn{5}{|c|}{ Body language } \\
\hline \multicolumn{5}{|c|}{ Innate / Natural } \\
\hline \multicolumn{2}{|c|}{ Interventions } & Body & Extremities & $\begin{array}{l}\text { Head and } \\
\text { neck }\end{array}$ \\
\hline \multirow[t]{2}{*}{ Orientation } & $\begin{array}{l}\text { Multi- } \\
\text { directional }\end{array}$ & Move-hips & Move arms & $\begin{array}{ll}\text { Move } & \text { your } \\
\text { neck } & \end{array}$ \\
\hline & $\begin{array}{l}\text { Uni- } \\
\text { directional }\end{array}$ & Turning back & $\begin{array}{l}\text { Bend your } \\
\text { knees up }\end{array}$ & $\begin{array}{ll}\text { Open } & \text { your } \\
\text { mouth } & \end{array}$ \\
\hline \multirow[t]{3}{*}{ Proximity } & Close & $\begin{array}{l}\text { Getting } \\
\text { closer }\end{array}$ & $\begin{array}{l}\text { Touch the } \\
\text { screen }\end{array}$ & Tilt head \\
\hline & $\begin{array}{l}\text { Un- } \\
\text { determined }\end{array}$ & $\begin{array}{l}\text { Intermediate } \\
\text { distance }\end{array}$ & Separated & Move neck \\
\hline & Far & Distant & $\begin{array}{l}\text { Close (at } \\
\text { your sides) }\end{array}$ & $\begin{array}{l}\text { Put head } \\
\text { backwards }\end{array}$ \\
\hline \multirow[t]{2}{*}{ Pose/Form } & Stopped & Standing & Frontal feet & Fixed look \\
\hline & Movement & $\begin{array}{l}\text { Jump on } \\
\text { your way }\end{array}$ & Move wrists & Nod \\
\hline \multirow[t]{2}{*}{ Speed } & Fast & Running & Move fingers & Deny \\
\hline & Slow & Walk & $\begin{array}{|ll|}\begin{array}{l}\text { Move } \\
\text { elbow }\end{array} & \\
\end{array}$ & Wink \\
\hline \multirow[t]{12}{*}{ Expression } & Complicity & $\begin{array}{l}\text { Move your } \\
\text { body closer }\end{array}$ & $\begin{array}{l}\text { Crossing fin- } \\
\text { gers }\end{array}$ & Nod \\
\hline & Honest & $\begin{array}{l}\text { Straighten } \\
\text { body }\end{array}$ & Hands out & Look directly \\
\hline & Clear & $\begin{array}{l}\text { Straighten } \\
\text { body }\end{array}$ & Arms open & Open look \\
\hline & Doubt & $\begin{array}{l}\text { Turn, leave, } \\
\text { come back }\end{array}$ & $\begin{array}{l}\text { Move shoul- } \\
\text { ders }\end{array}$ & $\begin{array}{l}\text { Doubtful } \\
\text { look }\end{array}$ \\
\hline & Happy & $\begin{array}{l}\text { Cry from } \\
\text { happiness }\end{array}$ & $\begin{array}{l}\text { Walk } \\
\text { dancing }\end{array}$ & Smile \\
\hline & Sickly & $\begin{array}{l}\text { Hunched } \\
\text { back }\end{array}$ & $\begin{array}{l}\text { Hunched } \\
\text { shoulders }\end{array}$ & Look down \\
\hline & Rational & $\begin{array}{l}\text { Bend over } \\
\text { body }\end{array}$ & Walk upright & $\begin{array}{l}\text { Touch your } \\
\text { chin }\end{array}$ \\
\hline & Intimate & Dancing & $\begin{array}{l}\text { Play with } \\
\text { your hands }\end{array}$ & Stern look \\
\hline & Lunatic & $\begin{array}{l}\text { Body in ten- } \\
\text { sion }\end{array}$ & Stiff arms & Startled look \\
\hline & Calm & $\begin{array}{l}\text { Sitting } \\
\text { slowly }\end{array}$ & $\begin{array}{l}\text { Relaxed } \\
\text { hands }\end{array}$ & Relaxed look \\
\hline & Social & $\begin{array}{l}\text { Sitting on the } \\
\text { floor }\end{array}$ & Hands out & $\begin{array}{l}\text { Look } \\
\text { forward }\end{array}$ \\
\hline & Relaxed & $\begin{array}{l}\text { Making slow } \\
\text { movements }\end{array}$ & $\begin{array}{l}\text { Move hands } \\
\text { slowly }\end{array}$ & $\begin{array}{ll}\text { Move } & \text { neck } \\
\text { slowly } & \end{array}$ \\
\hline
\end{tabular}

- Orientation: multi-directional and unidirectional. These are exclusive values.

- Proximity: close, intermediate and far. These are exclusive values.

- Pose/form: stopped and movement. These are not exclusive values. For instance, someone may be stopped without displacing, but changing the position of an extremity.

- Speed: fast and slow. These are exclusive values.

- Expression: complicity, frank, clear, happy, rational,
Table II

BODY LANGUAGE OF ACQUIRED GESTURES

\begin{tabular}{|c|c|c|c|c|}
\hline \multicolumn{5}{|c|}{ Gesture. Non-verbal communication } \\
\hline \multicolumn{5}{|c|}{ Body language } \\
\hline \multicolumn{5}{|c|}{ Acquired / Learnt } \\
\hline \multicolumn{2}{|c|}{ Interventions } & Body & Extremities & Head \\
\hline \multirow[t]{2}{*}{ Orientation } & $\begin{array}{l}\text { Multi- } \\
\text { directional }\end{array}$ & $\begin{array}{l}\text { Greet sev- } \\
\text { eral people }\end{array}$ & Shake hands & Turn your head \\
\hline & $\begin{array}{l}\text { Uni- } \\
\text { directional }\end{array}$ & Reverence & Point & $\begin{array}{l}\text { Fixed look de- } \\
\text { noting interest }\end{array}$ \\
\hline \multirow[t]{3}{*}{ Proximity } & Close & Bother & hugging & \begin{tabular}{|lr} 
Cover & your \\
mouth & when \\
yawning & \\
\end{tabular} \\
\hline & $\begin{array}{l}\text { Un- } \\
\text { determined }\end{array}$ & \begin{tabular}{|l|} 
Move \\
closer \\
to greet \\
someone
\end{tabular} & $\begin{array}{ll}\text { Raise } & \text { your } \\
\text { hand to } & \text { greet } \\
\text { someone } & \end{array}$ & $\begin{array}{ll}\text { Scratch } & \text { your } \\
\text { head } & \end{array}$ \\
\hline & $\overline{\text { Far }}$ & $\begin{array}{|ll|}\begin{array}{l}\text { Say } \\
\text { bye }\end{array} & \text { good } \\
\end{array}$ & $\begin{array}{l}\text { Say bye with } \\
\text { your arm }\end{array}$ & \begin{tabular}{|lr} 
Raise & your \\
head & in \\
greeting, & \\
from a distance
\end{tabular} \\
\hline \multirow[t]{2}{*}{ Pose/Form } & Stopped & $\begin{array}{l}\text { Sitting } \\
\text { down }\end{array}$ & Cross hands & $\begin{array}{l}\text { Leaning your } \\
\text { head on the } \\
\text { wall }\end{array}$ \\
\hline & Movement & \begin{tabular}{|l|} 
Getting \\
closer/away
\end{tabular} & Move toes & $\begin{array}{l}\text { Move } \\
\text { eyebrows }\end{array}$ \\
\hline \multirow[t]{2}{*}{ Speed } & Fast & Swing hips & $\begin{array}{l}\text { Wave with your } \\
\text { hand }\end{array}$ & $\begin{array}{l}\text { Shaking the } \\
\text { head }\end{array}$ \\
\hline & Slow & $\begin{array}{l}\text { Move } \\
\text { your back } \\
\text { slowly }\end{array}$ & Laying down & Move cheeks \\
\hline \multirow[t]{12}{*}{ Expression } & Complicity & Hug & $\begin{array}{l}\text { Crossing } \\
\text { fingers }\end{array}$ & Winking \\
\hline & Honest & $\begin{array}{l}\text { Straighten } \\
\text { body }\end{array}$ & Hands out & Look forward \\
\hline & Clear & $\begin{array}{l}\text { Have a re- } \\
\text { laxed atti- } \\
\text { tude }\end{array}$ & $\begin{array}{l}\text { Relaxed } \\
\text { arms/shoulders }\end{array}$ & Look directly \\
\hline & Doubt & $\begin{array}{l}\text { Shrug your } \\
\text { body }\end{array}$ & $\begin{array}{ll}\begin{array}{l}\text { Shrug } \\
\text { shoulders }\end{array} & \text { your } \\
\end{array}$ & $\begin{array}{l}\text { Raise your eye- } \\
\text { brows and stern } \\
\text { look }\end{array}$ \\
\hline & Happy & Jumping & Raise arms & $\begin{array}{ll}\text { Open } & \text { your } \\
\text { mouth } & \end{array}$ \\
\hline & Sickly & $\begin{array}{l}\text { Shruged } \\
\text { body }\end{array}$ & $\begin{array}{l}\text { Shoulders } \\
\text { down }\end{array}$ & Sad look \\
\hline & Rational & $\begin{array}{l}\text { Body } \\
\text { upright }\end{array}$ & Stretched arms & Head up \\
\hline & Intimate & $\begin{array}{l}\text { Laying } \\
\text { down }\end{array}$ & Touch your hair & $\begin{array}{l}\text { Suggestive } \\
\text { look }\end{array}$ \\
\hline & Lunatic & Stiff body & \begin{tabular}{|l|} 
Move \\
shoulders \\
fast/stiff arms
\end{tabular} & Eyes wide open \\
\hline & Relaxed & $\begin{array}{l}\text { Sit down } \\
\text { slowly }\end{array}$ & $\begin{array}{l}\text { Hands in your } \\
\text { pocket }\end{array}$ & Relaxed look \\
\hline & Social & $\begin{array}{l}\text { Body } \\
\text { sitting }\end{array}$ & $\begin{array}{l}\text { Crouching } \\
\text { down }\end{array}$ & $\begin{array}{l}\text { Nice look and } \\
\text { smile }\end{array}$ \\
\hline & Calm & $\begin{array}{l}\text { Relaxed } \\
\text { body }\end{array}$ & $\begin{array}{l}\text { Relaxed arms/ } \\
\text { shoulders }\end{array}$ & Relaxed look \\
\hline
\end{tabular}

lunatic, doubtful, sickly, intimate, relaxed, calm and social. These values are not exclusive. 
Table III

SOUND LANGUAGE OF NATURAL \& ACQUIRED GESTURES

\begin{tabular}{|c|c|c|c|}
\hline \multicolumn{4}{|c|}{ Gesture. Non-verbal communication } \\
\hline \multicolumn{4}{|c|}{ Sound language } \\
\hline \multicolumn{4}{|c|}{ Innate / Natural } \\
\hline \multicolumn{4}{|c|}{ Acquired / Learnt } \\
\hline \multicolumn{2}{|c|}{ Interventions } & Personal & Environment \\
\hline \multirow[t]{12}{*}{ Emotional } & Complicity & $\begin{array}{l}\text { Whistle some- } \\
\text { one }\end{array}$ & greetings \\
\hline & Frank & Assent/Nod & Assent/Nod \\
\hline & Clear & Assent & Assent/Nod \\
\hline & Doubt & $\begin{array}{lr}\text { Make noises } \\
\text { with your } \\
\text { mouth closed }\end{array}$ & $\begin{array}{l}\text { Clear } \quad \text { your } \\
\text { throat }\end{array}$ \\
\hline & Happy & Guffaws/laugh & Laughter \\
\hline & Sickly & $\begin{array}{l}\text { Puff/snort } \\
\text { slowly }\end{array}$ & Complain \\
\hline & Rational & Assent/Nod & $\begin{array}{ll}\text { Nod/ Assent } \\
\text { with a mouth } \\
\text { sound }\end{array}$ \\
\hline & Intimate & Whisper & Whisper \\
\hline & Lunatic & Shout & Scream \\
\hline & Relaxed & $\begin{array}{l}\text { Make soft } \\
\text { sounds }\end{array}$ & $\begin{array}{l}\text { Make soft } \\
\text { sounds }\end{array}$ \\
\hline & Social & Make a hubbub & Make a hubbub \\
\hline & Calm & Sigh & Sigh \\
\hline \multirow[t]{2}{*}{ Context } & Alone & Whistle & $\begin{array}{l}\text { Environment } \\
\text { sounds }\end{array}$ \\
\hline & Accompanied & Whistle & Blow \\
\hline \multirow[t]{2}{*}{ Internal } & Silence & Hiss & Hiss \\
\hline & Sound & Clap & Cheer \\
\hline \multirow[t]{2}{*}{ External } & Silence & Hiss & Hiss \\
\hline & Sound & Clap & Cheer \\
\hline
\end{tabular}

Table IV

PARAMETERS OF BODY AND SOUND LANGUAGE

\begin{tabular}{|l|l|l|l|l|l|l|}
\hline \multicolumn{5}{|c|}{ Body language } \\
\hline Orientation & Proximity & Pose/Form & Speed & Expression & Type & Place \\
\hline
\end{tabular}

\begin{tabular}{|l|c|c|c|c|c|}
\hline \multicolumn{5}{|c|}{ Sound language } \\
\hline Emotional & Context & Internal & External & Type & Scope \\
\hline
\end{tabular}

- Type: acquired/learnt and natural. These are exclusive values.

- Place: body, extremities and face. These values are exclusive.

As illustrated in Table IV, the concept of Sound language is composed of six parameters: emotional, context, internal, external, gesture type and scope. The possible values for each parameter listed and whether they are mutually exclusive or not:

- Emotional: complicity, frank, clear, happy, lunatic, rational, doubtful, sickly, intimate, relaxed, calm and social. These values are not exclusive.
Table V

COMBINATION OF BODY LANGUAGE PARAMETERS

\begin{tabular}{|c|c|c|c|c|c|c|c|}
\hline \multirow{2}{*}{ 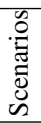 } & \multicolumn{7}{|c|}{ Body language } \\
\hline & $\begin{array}{l}\text { Orien- } \\
\text { tation }\end{array}$ & $\begin{array}{l}\text { Proxi- } \\
\text { mity }\end{array}$ & $\begin{array}{l}\text { Pose / } \\
\text { Form }\end{array}$ & Speed & $\begin{array}{l}\text { Expre- } \\
\text { ssion }\end{array}$ & Type & Place \\
\hline $\mathrm{S} 1$ & $\begin{array}{l}\text { Multidi- } \\
\text { rectional }\end{array}$ & Close & Stopped & Fast & $\begin{array}{l}\text { Calm, } \\
\text { Rational }\end{array}$ & Acquired & $\begin{array}{l}\text { Extre- } \\
\text { mities }\end{array}$ \\
\hline $\mathrm{S} 2$ & $\begin{array}{l}\text { Multidi- } \\
\text { rectional }\end{array}$ & $\begin{array}{l}\text { Inter- } \\
\text { mediate }\end{array}$ & Stopped & Slow & $\begin{array}{l}\text { Calm, } \\
\text { Rational }\end{array}$ & Natural & Face \\
\hline S3 & $\begin{array}{l}\text { Multidi- } \\
\text { rectional }\end{array}$ & Far & $\begin{array}{l}\text { Move- } \\
\text { ment }\end{array}$ & Fast & $\begin{array}{l}\text { Calm, } \\
\text { Rational }\end{array}$ & Natural & Body \\
\hline
\end{tabular}

- Context: alone or accompanied. These values are exclusive.

- Internal: silence and sound. These are exclusive values.

- External silence and sound. These values are exclusive.

- Type: acquired/learnt and natural. These values are exclusive.

- Scope: personal and environment. These values are exclusive.

B. Combination of the parameters of the table to specify interaction scenarios

In order to simplify the table and make it easier to read, the parameters of one of the tables will be fixed and the parameters of the second table will be permuted, repeating this process twice to be able to attain permutation of the parameters of both tables. To be brief, we will only present an example of the first interaction, generating just three representative scenarios focusing in the case of an art museum.

To start with this process, the parameters of the table on Sound language will be fixed and only the parameters of the table on Body language shall be permuted.

The values fixed from the table of Sound language are: Emotional: calm, rational / Context: alone / Internal: sound / External: silence / Type: acquired / Scope: environment.

By fixing these parameters we are filtering a great amount of possible scenarios. Through them we specify that the sound will cause certain sensations of calm and rationality and that there will only be a single sound source. There is some sound inside the building where the interaction is being performed and no external sound can be perceived. Besides, the sound comes from the environment.

Once the parameters of the table of Sound language are fixed, the parameters of the table of Body language are permuted to obtain three of the most prominent scenarios. The result of such parameter combination is shown in Table V.

- Scenario S1: A high school student named Luis has decided to visit an art museum on Friday afternoon to broaden the content of his second History examination on the life of Velazquez. Luis is standing facing the work "Las Meninas" and his interest is to obtain 
information on the painting. The interaction form will be using fast gestures with his extremities, he has learnt these gestures from an audio-guide located next to the entrance of the museum. Luis' expression is calm and rational.

- Scenario S2: Laura, a History teacher, visits the art museum to see the new facilities after a reform in the museum. She is located at a certain distance from the works. Her interest lies on obtaining information on the new works added. Laura's interaction form with the works will be using slow and natural face gesture, which shall not imply any effort for her. Laura has a calm and rational expression.

- Scenario S3: Once Luis has finished gathering the information he needed on the work "Las Meninas", he decides to search for more works by Velazquez. Luis is walking quite far from the works. His interest is to find works by this painter. The interaction form to search for more works will be using fast and natural body gestures, which will not imply any effort. Luis' expression remains calm and rational.

\section{CONCLUSION AND FUTURE WORK}

This paper can be used as a definition of meaning of gesture, both at theoretical and practical level (exemplification of multiple scenarios with the permutation of its different parameters). These interconnections generate dynamic meeting spaces with multiple implications in the field of technology (new metaphors and new forms of interaction, which imply new devices and their interrelationships).

The entire process described has been illustrated using a set of specific scenarios starting from the scenario of the Art Museum, but this technology could be tested in many other environments.

In the same way - using the concepts, tools and techniques described in this paper - it is possible to consider the challenge of defining new interaction forms based on gestures, as well as describing interaction metaphors, which enrich the intuitive comprehension of those new forms of interaction.

\section{ACKNOWLEDGMENT}

This research paper has been funded by the CDTI, project CENIT-2008-1019 and project CICYT TIN200806596-C02-01.

\section{REFERENCES}

[1] S. Molina, "HUI o gestos tangibles," in Proceedings of the 9th Congreso Internacional de Interaccin Persona-Ordenador, J. A. Gallud and M. D. Lozano, Eds., 2008, pp. 325-340.

[2] D. Saffer, Designing Gestual Interfaces. O'Reilly, 2009.

[3] B. Moggridge, Designing Interactions. MIT Press, October 2007.
[4] J. Tidwell, Designing Interfaces (Patterns for Effective Interaction Design). O'Reilly, November 2005.

[5] D. A. Norman, The Design of Every Things. Basic Books, November 2002

[6] — The Design of Future Things. Basic Books, November 2007.

[7] B. Shneiderman, "Creating creativity: user interfaces for supporting innovation," ACM Trans. Comput.-Hum. Interact, vol. 7, no. 1, pp. 114-138, 2000.

[8] — - "Leonardo's laptop: human needs and the new computing technologies," in Proceedings of the 14th ACM International Conference on Information and Knowledge Management, October 2005, p. 1.

[9] — - "Creativity support tools: accelerating discovery and innovation," Commun. ACM, vol. 50, no. 12, pp. 20-32, 2007.

[10] H. Ishii, "The tangible user interface and its evolution," Commun. ACM, vol. 51, no. 6, pp. 32-36, 2008.

[11] A. Sellen, Y. Rogers, R. Harper, and T. Rodden, "Reflecting human values in the digital age," Commun. ACM, vol. 52, no. 3, pp. 58-66, 2009.

[12] Make me minimal, Innovación y usabilidad: el graffiti 3D, 2010 (accessed 2010). [Online]. Available: http://makememinimal.com/2008/ innovacion-y-usabilidad-el-graffiti-3d/

[13] Panasonic, Panasonic's Interactive TV Wall, 2010 (accessed 2010). [Online]. Available: \url\{http://www.youtube.com/ watch?v=P8GriGd6vdU\&feature $=$ related $\}$

[14] Crazy Multi-Input Touch Screen, 2010 (accessed 2010). [Online]. Available: \url\{http://www.tengounmac. com/archivo/retorna-pantalla-tactil-de-jeff-han.xhtml\}

[15] V. Flusser, Los Gestos. Ed. Herder, 1994. 